present the outer upper and the inner lower are rudimentary. The canines are absent in all ; the full complement of molars are present, of similar character, and degenerating at either end ; they are formed on the Lophiodon type; the outer wall is very strong and oblique, with the cusps but little developed and the cingulum large behind ; the posterior transverse ridge sends forward a process from near its middle, which in one fossil species ( $R$. tichorhinus) is met by another from the anterior wall to form a circular foramen behind the anterior fossa. The lower molars agree with those of Palæotherium, being formed of a double crescent, in which the posterior cornu of the front lunule is partially overlapped by the anterior cornu of the hind one; no third crescent is found on the last molar; three toes are present on all the limbs. They have not been found fossil in the Eocene strata, consequently the American species are among the earliest. Leidy has named an allied genus of small size Hyracodon. Its teeth resembled rhinoceros, but the anterior premolars were retained; the peculiar uncus on the posterior transverse ridge was wanting, and the proportions of the incisors were reversed. There are several extinct species of the genus Rhinoceros. Acerotherium possessed the same number of teeth as the Asiatic genera, but the nasal bones were small, slender, and smooth above, so they could scarcely have carried a horn; it is a Miocene form only; a fifth rudimentary toe was present. Except $R$. pleuroceros, which had two laterally-placed tubercles on the nasal bones, all the other species had them median. They may be divided by their incisors, as are the recent genera, some having them rudimentary, others not. All the European specimens had two horns, with or without functional incisors. The English species, which are not peculiar, are from Pliocene and Pleistocene formations; in $R$. leptorhinus the nasal septum was not ossified; in others it was much so, as in $R$. tichorhimus, a species which has been found preserved by ice in the river Vilni, a branch of the Lena, in Siberia ; it possessed a hairy coat and the peculiar pit in the molars mentioned above.

From Port St. Julian, in Patagonia, Mr. Darwin first obtained bones of the peculiar genus Macrauchenia, which has not been found out of South America, and only in the Pleistocene deposits there. Prof. Huxley has proved the existence of a second smaller species from some fragments out of a copper mine in Bolivia. Owen showed in his, the first description of the animal, that the vertebræ were peculiar, and agreed with those of the Camels in having the vertebral artery threading a bony canal inside the spinal column, instead of through the bases of the transverse processes. It may be remarked that Myrmecophaga exhibits a similar conformation. But these vertebræ in Macrauchenia are further peculiar in having both ends of the centra quite flat instcad of their being opisthocœlous, as in the allied forms. M. Bravard, who was killed in the earthquake at Mendoza, left excellent drawings of the skull and other parts of this animal, which Prof. Burmeister has since published. From them we learn that the skull was not unhorselike; the orbital ring was complete; the palate was not fully ossified between the posterior molars (the camels present the same peculiarity, though Artiodactylate); the nasal bones were extremely reduced, so that the anterior nares were directly above the posterior, and the lower jaw had the angle prolonged. Burmeister thinks, and with good reason, that the animal possessed a fair-sized trunk. There were twenty-four dorso-lumbar vertebræ, of which seventeen were dorsal. The radius and ulna, as well as the tibia and fibula, were fused throughout. The femur possessed an extremely small third trochanter; and there were three toes to each limb. The astragalus was strongly Perissodactylate, no cuboid facet being present. Our knowledge of the teeth is somewhat deficient, as they are always preserved in a much worn state. The typical forty-four were present ; the incisors were equine, and the canines of the same size; the back. molars were the bigger and the anterior premolars comparatively simple. The lower molars formed double crescents, as in Palæotherium.

In tracing back the descent of the Equida, the Palæotherium d'Orleans of Cuvier has been shown to be generically different, and has been called Anchitherium ; it is also found in Nebraska. These were small horse-like animals with teeth much as in Palæotherium, forty-four in number; the first premolars were very small, and no pit was present in the incisors ; the outer wall of each molar was also concave opposite the cusps; the lower molars formed double crescents, and the last possessed the extra lobe. The ulna and fibula were fused with the radius and tibia respectively; the astragalus had some of the obliqueness of that of the horse, which it resembled in many other points. But there were three toes on the limbs, the lateral ones being less strong than the median. A peculiar antorbital fossa was present.

The horse must be described before the affinities of its close allies can be realised. In it the incisors possess the well-known pit; the canines are rudimentary in the mare; the premolars resemble the molars, and the crowns are very long and deeply embedded, with a concave crescent opposite the tubercles on the outer wall and the anterior internal tubercle insulated at first; otherwise they are typical. The depressions are very deep and are filled up by cementum, to form a solid mass. The lower molars are slightly complicated double crescents. The ulna and fibula are not free. Hipparion had very horse-like teeth. It is a later Miocene form, and is common in the New and Old World. It possessed the antorbital pit, as in Anchitherium, but was otherwise very equins. The canines were present in both sexes of equal size, and the anterior internal tubercle of the molars was completely insulated. The median of the three digits alone was functional. Merychippus, a Pliocene form, recognised by Leidy from some teeth, seems to have been an intermediate form between these and Anchitherium. Fossil true horses abound in America as well as the Old World; they since became extinct in the former locality. They are found in the Pleistocene nearly everywhere ; their earliest remains are from the Sevalik Hills.

With these animals the description of the fossil Perissodactylata terminates.

\section{PERCEPTION IN THE LOWER ANIMALS}

ETTERS on this interesting subject still continue to pour in upon us in so great abundance that limited space compels us to select merely the facts contained in each. The best service we can at present render to the unravelling of the, we think, yet unsolved problem is simply to accumulate facts; no doubt a satisfactory explanation will by-and-by be arrived at. First we must give place to Prof. Croom Robertson, who thus writes as to the theory broached in his former letter :-

In my former letter I made no pretension to explain all the wonderful feats reported of dogs or other animals, but only argued, in the wake of Mr. Wallace, that it had never been sufficiently considered what help in finding their way dogs might have from smell alone. Be the help what it may in the particular cases, I thought it clear that, if in their common experience smell does not somehow supply to dogs the defect of touch, they are, as far as we can see, badly fitted out, by comparison with men, for making their way through the world. And, even after your article of last week, I must still in their interest hope that the notion of a continuous world of smells is not an impossible one.

If the external world were the same to dogs that it is to mena complex of interwoven touches and sights in space, and only in addition dogs had more frequent and varied experiences of smell, the dying away or shifting of some in a particular train of odours would doubtless, as the writer of the article urges, put a dog out 
when reduced to work its way back along such a train. But my point is, that a dog will regularly think of all things, stationary or moving, by their smell, where we think of them by their touch as bandled, and this upon the simple ground of fact that a dog has no hands; in which case the continuity of a road will as little :o the dog as to us depend upon the standing-still of flocks of sheep or any other passing objects. It is true that our experience does not enable us easily to fancy what sort of world this of the dog's will be, but at the worst we need not conceive it, with the writer, upon the analogy of a succession of coloured mists. Do we, even with our intermittent smell, find it so impossible to refer the diffused odour of a dung-hill to a particular source? Or, to take a fair parallel case, if a sound is diffused so that it may be heard anywhere throughout a great hall, do we therefore suppose it to be everywhere and not to emerge from a detinite spot? To the psychologist the strictly tactile properties of objects are themselves but sensations, which we are determin $=d$ to pr,ject away from $u$ - in a cert iin definite order-as it happ ${ }^{\circ}$;, a very sharply defined order. W th different means of proje: in and different se:sations to project, how shousd the dog nut have its own different world - the best it can devise out of its experiences?

Such reference to the fact of a dog's organs of sense being what they o'vioully are, ought not to be discounted as mere speculatiın, but perhaps that must be b rne with. Facts of the other sort-renorts, more or less authentic, of the feats of particular dogs-wheit made a ground for ascribing to the species preter tatural powers of divinati $n$, merely because the facts are not explicabie under the conditions of human experience, are beset with their own difficulty. Dogs do not always find their way back, even from the next s'reet. Let all that side of the matter be thonghe of, before we supp se some unerring instinct to acc unt for the remarkable enough feats of some that cannot be $d$-nied. Of course no train of evanescent smells can guide a ding back upon a road from which they have died away; as little, or s'ill less, can the succession of particular smells, however constant, lead a dog right upon a line that he has never travelled over nefore. But that dogs, while they have no such touch as ours, ro constantly use therr sense of smell to guide them, canno be roubted; and the result to them must be such a very different world of experience from ours, though developed under common law's of acquisition, that we have no means of deciding what is impossible to be done by some dogs through mere experience.

One of your correspondents, Mr. Brewer, had good remarks in this sense the other week. One point he raised besides upon which I would add a word. The point was whether for the dog smells would enter, instead of touches, into that fundamental experience of an external world, of which visual sensations are but marks or symbols. I should imagine th th they would enter into its experience of modes of extension, by us acquired chiefly through the moving hand. But into the experience of modes of res stance, the general tactile sensibility diffused over the surface of the budy would enter for the dog as well as for us.

Mr. George Henry Lewes appends to his letter on p. 4OI of this week ${ }^{3}$ s NATURE, the following contribution to this subj:ct :-

Gratiolet, in his work on the "Nervous System," mentions that a doy of his was always thrown into cunvulsions of terror by the scent of a small piece of wolf's skin, which was so old that it was worn to a shred. In my room there is a perfectly unworn wolfskin made into a rug, and on this my bulldog was accustomed luxuriously to stretch himself, without any but plezsurabl- emotions. Now this may have been due either to his impe fect s-n-e of smell, or, what is more prohable, to his not having iuherited any terror from ancestors more likely to attack than to be afraid of a wolf.

Mr. Laughton, of the Royal Naval College, Greenwich, sends us a valuable letter, from which we extract the following :-

A passage in Sir Bartle Frere's paper on Cutch (Journal of the Royal Geographical Society, vol. xl. p. I86), seems to bear on this subject which has been interesting the rearters of NA'TURE for some weeks past. He says:- "As el ewliere in the plain country of Sind, and here more conspicuounly, owing to the absence of any prominent natural features or marked tracts, the best guides srem to depend entirely on a kund of instinct-they will generally indicate the exact bearing of a distant point which is not in sight quite as accurately as a common compass would give it to one who knew the true bearing. They affect no mysterious knowledge, but are generally quite unable to give any reason for their conclusion, which seenis the result of an instinct-like that of dogs and horses and other animals-unerring, but not founded on any process of reasoning, which others can trace or follow."

I incline strongly to the solution put forward by the writer in the Quarterly (see letter in last number). If to this we add the consideration that dogs certainly can and do interchange ideas, and may therefore question other dogs as to the general direction in which they wish to go, the two together seem to offer a reasonable though hypothetical explanation of the very curious facts referred to.

Mr. George R. Jebb, of Shrublands, Chester, writing on March 18 , says-

Last Thursday I sent my terrier dog (Tartar) by train from Chester to Shrewsbury by Great Western Railway (i $e$. by way of Wrexham and Ruabon', I myself went by the North Western line via Broxton and Whitchurch; the distance by the former road is 42 miles, by the latter 38 : the two railways diverge from each other for some 20 miles from Chester, and are then $\mathrm{I} 6$ miles apart ; they afterwards converge and join at Shrewsbury. Tartar was sent from Shrewsbury to Broxton station, which is ro miles from Chester, by the 2.55 train. I had previously arranged with the station-master to keep the dog for five or ten minutes after the departure of the train, and then to set him at liberty on the public road. The train arrived at Broxton at four o'clock. Tartar hung about the station till nearly 5.30 , perhaps longer, as he was not seen starting off. He was at home at Chester at nine; he was not at all distressed. It is probable, I think, that he came back pretty direct. It is certain he came across ten miles of country, the greatest part of which he had never traversed before. It is also certain he did not return viâ Shrewsbury, as there was not time. $\mathrm{He}$ had never been at Broxton before.

Does not this experiment seem to prove that dogs-some at least-possess the wonderful power (the nature of which is at present unknown) of arriving at the knowledge of the direction of their home when they have been taken from it long distances by circuitcus routes? And if so, is it not more probable that a dog when lost usually makes use of this power to guide himself home by the shortest practicable road, than that he finds his way back "by means of the odours he took note of" on the outward journey? How do pigeons find their way home? A railway con. tractor told me he has a pony which he uses chiefly for drawing a light "lorry" upon a tramway now in course of construction. There are on this tramway some loops or passing places for waggons at intervals of a mile or so. These points are dangerous if passed too quickly. The contractor drives the pony himself often at a very fast rate. The pony will on the darkest nights suddenly pull up at the dangerous points without the slightest check troin the driver, who otherwive would be obliged to proceed with the greatest caution. Doss the pony know his whereabouts by the sense of : mell, hearing, or touch? Probably, I should say, by all three acting in unison.

The Rev. O. Fisher, of Harlton, writes :-

On a bright day when I have" flowers in my window, bees frequently precipitate themselves against the window-panes, evidently desirous of reaching the plants. This is easily explained by the sense of sight; but the remarkable thing is that they do the same when the blind is drawn down, so that they cannot see the flowers, and it seems impossible that they should smell them while the window is shut. Can it be that that allpervading ather, which brings lig it to our eyes, and is also b-lieved to convey the inagnetic and electric forces tnrough media impervious to light, may act in a manuer o her than luminiferous towards some animals, and produce "action at a distance" upon their organs?

A Scotch correspondent, R. C., who has given us his full name and address, sends us the following interesting facts :-

A few years ago a sheep, one of a flock, belonging to Mr. Miller, flesher, Beith, Ayrshire, gave birth to three lambs; thinking that three were too heavy for the mother to suckle, he gave one to a farmer, who lived three quarters of a mile from the field where the shsep lambed, This one was taken away from the mother when barely a day old, and carried to the farmer's, where it was shut up in a close house, - 
Two days after it found its way out, the door having been left open, and immediately made off for the field from which it had been taken. The writer met it near the field walking (it having chosen rightly between two branches into which the road diverges between the field and the farm-house) on the grass on the side of the road : the farmer, an old man, was in pursuit, and called upon the writer to turn it back, which he did, but not without some difficulty, as it crossed from side to side, and made efforts to pass on, with all the tactics of an old animal, while it was barely three days old, and had been barely one when it was brought from the field. - I have the following from a well-authenticated source. A farmer in Bogside, Beith, of the name of Fleming, was looking out of his window one summer's morning, about three o'clock, when he saw a fox crossing a field before it, carrying a large duck that he had captured. On coming to a stone dyke about four feet high, on the side of the field, Reynard made an effort to leap over it with his prey, but failed, and fell back into the field. After making three attempts with the same result, he sat down and viewed the dyke for a few minutes; after apparently satisfying himself, he caught the duck by the head, and standing up against the dyke with his fore paws, as high as he could reach, he placed the bill of the duck in a crevice in the wall; then springing upon the top, he reached down, and pulling up the duck dropped it upon the other side, leaped down, and pickmn it up, went on his way. If this is not reason, it is nearly akin to it.

We conclude with the following instances sent us by Mr. G. J. Romanes, of Cornwall Terrace, Regent's Park:-

A Colley dog accompanied his master with a flock of sheep down the Caledonian Canal, and between Ooan and Greenock suffered much from sea-sickness. Several months afterwards a similar journey was undertaken by the same dog and man with another flock of sheep. Upon quitting the wharf at Oban, the $\mathrm{dog}$, remembering that this was the point at which his troubles began on the former occasion, jumped ashore, leaving his master with the sheep on board the steamer. Upon landing at Greenock the man was surprised to find his dog upon the quay awaiting his arrival-the animal having run by land from one whart to the other, over ground which he had never before traversed. The distance between Oban and Greenock is fifty miles in a straight line, but as this passes over high mountains as well as through a lake and two ainrs of the sea, it is not likely to have been the route taken.

My authority for this account is a leading clergyman in Glasgow, who would, no doubt, be willing to give his name to any one desiring it.

The second instance, in its bearing upon Mr. Wallace's theory, is even more conclusive. Another dog of the same kind sailed with his master from Wick to Berwick, where he was lost. Ten (?) days afterwards he appeared at his home in Sulherlandshire, footsore and exhausted, having, it must seem, run nearly the entire length of Scotland. I am indebted for this information to a medical army-officer and well-known C.B. who had heard it from the owner of the dog. As my friend is at present in ill-health, I am unable co refresh my memory as to the number of days occupied by the dog's return journey, but I think it is correctly stated.

\section{NOTES}

THE meeting to which we alluded last week in connection with a memorial to the late Prof. Sedgwick, was held on Tuesday, and was attended by a large number of scientıfic and university friends of the late eminent geologist. Resolutions were passed that a geological museum be erected, to be called the Sedgwick Museum, and that a bust of the professor should be placed in it. A Cambridge and a London Committee were appointed. The Prince of Wales wrote that the object of the meeting would have his warm support, from the feeling of respect he entertained for the late professor.

Sомe efforts are now being made gradually to give the same stimulus to the higher education of women as of men. The National Union for Improving the Education of Women has offered seven scholarships of $25 l$. each, tenable for one year, for competition throughuut the United Kingdom, the competitors to be young women over sixteen years of age. The scholarships will be awarded at the local examinations held during the present year by the Universities of Oxford, Cambridge, and Edinburgh, and Trinity College, Dublin, the Science and Art Department, the Society of Arts, and the College of Preceptors.

THF examiners for the Cambridge Natural Sciences Tripos for 1872 have represented to the Board of Natural Science Studies that they are of opinion that the time has now come when an increase in the number of examiners is urgently required. The amount of physics now included in the subjects of examination is so large as to make it impossible to treat the examination in this subject any longer as an appendage to the examination in chemistry. The subjects of comparative anatomy, zoology, and physiology are also too wide to be undertaken as a general rule by one examiner. An increase in the number of examiners to seven would make it much more often possible to secure a real examination of the answers by two examiners, which is unquestionably desirable. The Board therefore recommend that in Regulation Io for the Natural Sciences Tripos, for the words "two examiners" the words "three examiners" be substituted, and for the words "third examiner" the words "fourth examiner" be substituted, and for the words "five examiners" the words "seven examiners" be substituted. They recommend further that, in order to ensure the regular rotation of examiners, five examiners be nominated by the Buard in the present year, of whom one shall be nominated to hold office for one year only.

Mr. Arthur Milman, son of the late Dean of St. Paul's, has been appointed Assistant-Registrar to the University of London, in the room of Dr. Hirst.

IT is understood that Mr. Fowler, of Lincoln College, Oxford, author of the two works on Deductive and Inductive Logic, will be a candidate for the Professorship of Logic, vacant by the recent death of Prof. Wall. The appointment is made by Convocation.

-THE late Mr. Julius Brenchley, whose death a month ago has been a great loss to scientific collectors, as well as to the town of Maidstone, left as the results of his voyage in the South Pacific, the last of his most extensive travels, the manuscript together with the plates which illustrate it already drawn, of a work which he fully intended to have had printed, on the natural history of those regions. It is to be hoped that some means will be taken to insure their publication.

IT is satisfactory to find that that the new "Spanish Society of Natural History" is continuing its career undisturbed by the political troubles around it. The third part of its Annals bearing date March 5, 1873, has reached this country, and is quite up to the mark of the parts which have preceded it. It contains the conclusion of Vilanova's paper on " the Pre-historic in Spain ;" a catalogue, by Gundlach, of the mamifera of Cuna ; a paper by Sharp, des ribing a new species of Spanish Colcoptera, and containing the descripiions of several new blind beetles from the caves of the mountains of the Asturias; a paper, by Colmeiro, on the elevations attained by cultivated plants in Ecuador; also a long and careful paper by Colmeiro, on the Leguminosæ of Spain and Portugal. This part completes the first volume, and contains index, and list of the members of the Society. On inspecting the latter it appears that only two of our countrymen have joined the Society. This fact has, we believe, been a considerable disappointment to the founders of the Society, who hoped it would meet with a liberal support in this country. We hope that when the existence of the Society and the merit of its publications become more widely known, it will receive the recognition it desserves. 